DOI: https://doi.org/10.32838/2523-4803/69-4-33

УДК 332.3:332.2.021.8:332.33

\title{
Музика П.М.
}

доктор економічних наук, професор,

Львівський національний університет

ветеринарної медицини та біотехнологій імені С.З. Гжицького

Урба С.I.

кандидат економічних наук, доцент,

Львівський національний університет імені Івана Франка

\section{Гончаренко Л.В.}

тимчасово виконуючий обов'язки директора

департаменту агропромислового розвитку,

Львівська обласна державна адміністрація

\section{Muzyka Pavlo}

Stepan Gzhytskyi National University of

Veterinary Medicine and Biotechnologies Lviv

Urba Svitlana

Ivan Franko National University of Lviv

Goncharenko Ludmyla

Lviv Regional State Administration

\section{АНАЛІЗ СТАНУ ТА ЕФЕКТИВНОСТІ ВИКОРИСТАННЯ ЗЕМЕЛЬНИХ РЕСУРСІВ В УКРАЇНІ}

\begin{abstract}
У статті досліджено стан та ефективність використання земельних ресурсів держави. Проаналізовано структуру земельних ресурсів в Украӥні та в окремих краӥнах світу. Визначено, щзо найбільшу плошу у структурі земельного фонду становлять сільськогосподарські угіддя, підтверджено значний рівень розораності иієї території. Охарактеризовано земельні ресурси найбільших агрохолдингів Украӥни, а також визначено структуру діючих сільськогосподарських підприємств за розміром угідь. Досліджено рівень ефективності використання сільськогосподарських угідь в регіонах України на основі аналізу їх площ та рівня розораності, що дало змогу провести їх групування. Запропоновано стратегічні пріоритети, наведено комплекс заходів щчодо підвищення ефективності використання земельних ресурсів держави.
\end{abstract}

Ключові слова: земельні ресурси, землі сільськогосподарського призначення, сільськогосподарські угіддя, рівень розораності, ринок, сільське господарство.

Постановка проблеми. Сільське господарство як важливий та невід'ємний напрям економіки країни посідає провідне місце серед інших видів економічної діяльності. В сучасних умовах реалізацію потенціалу сільського господарства в Україні стримує низька ефективність використання земельних ресурсів насамперед через відсутність раціонально організованого ринку земель сільськогосподарського призначення. Це формує спектр дестабілізуючого впливу ризиків та загроз, серед яких слід назвати поглиблення процесів ірраціонального використання сільськогосподарських угідь та зниження рівня їх родючості, перешкоджання впровадженню довгострокових інвестиційних проектів в аграрній сфері, реалізацію корупційних схем зміни цільового призначення сільськогосподарських угідь, розвиток тіньового ринку землі, використання інструмента емфітевзису для фактичного придбання сільськогосподарських угідь.
Проблема відсутності сформованості ринку обігу земель сільськогосподарського призначення дестабілізує процеси забезпечення не лише економічної, але й національної безпеки держави у зв'язку з ризиками надмірної концентрації площ сільськогосподарських угідь у власності однієї особи, придбання землі іноземцями, часткової монополізація окремих сегментів аграрного ринку тощо.

Аналіз останніх досліджень і публікацій. Значний внесок у вирішення економічної проблеми дослідження ефективності використання земельних ресурсів зробили Д.І. Бабміндра, П.І. Гайдуцький, М.В. Гладій, Б.М. Данилишин, І.Г. Кириленко, М.Ф. Кропивко, I.I. Лукінов, I.P. Михасюк, В.М. Трегобчук, В.В. Юрчишин, А.Е. Юзефович та інші вчені. Проте, незважаючи на значну кількість робіт у цьому напрямі, недостатньо вивченими залишаються проблеми оцінювання ефективності використання земельних ресурсів України в 
умовах Євроінтеграції, що зумовлює необхідність продовження наукових розвідок для визначення методологічних та прикладних векторів цього процесу.

Постановка завдання. Метою статті є дослідження сучасного стану та оцінювання ефективності використання земельних ресурсів України задля формування основних стратегічних пріоритетів підвищення їх раціонального використання в умовах наявних дисбалансів.

Виклад основного матеріалу. Відповідно до Земельного кодексу України всі землі поділяються на категорії з різним цільовим призначенням. Землі, що використовуються для аграрного виробництва, $\epsilon$ землями сільськогосподарського призначення, які додатково поділяються на сільськогосподарські угіддя (рілля, багаторічні насадження, сіножаті, пасовища та перелоги) та несільськогосподарські угіддя (землі під господарськими будівлями та інфраструктурними елементами господарства) [3].

В Україні переважають ресурси сільськогосподарського використання. Основним ресурсом аграрного виробництва $є$ земля. Згідно з даними Державної служби статистики України у 2017 році загальна площа сільськогосподарських угідь в Україні дорівнювала 41 489,3 тис. га (з неї 32 544,3 тис. га складає рілля), що становить 68,7\% від загальної площі території держави

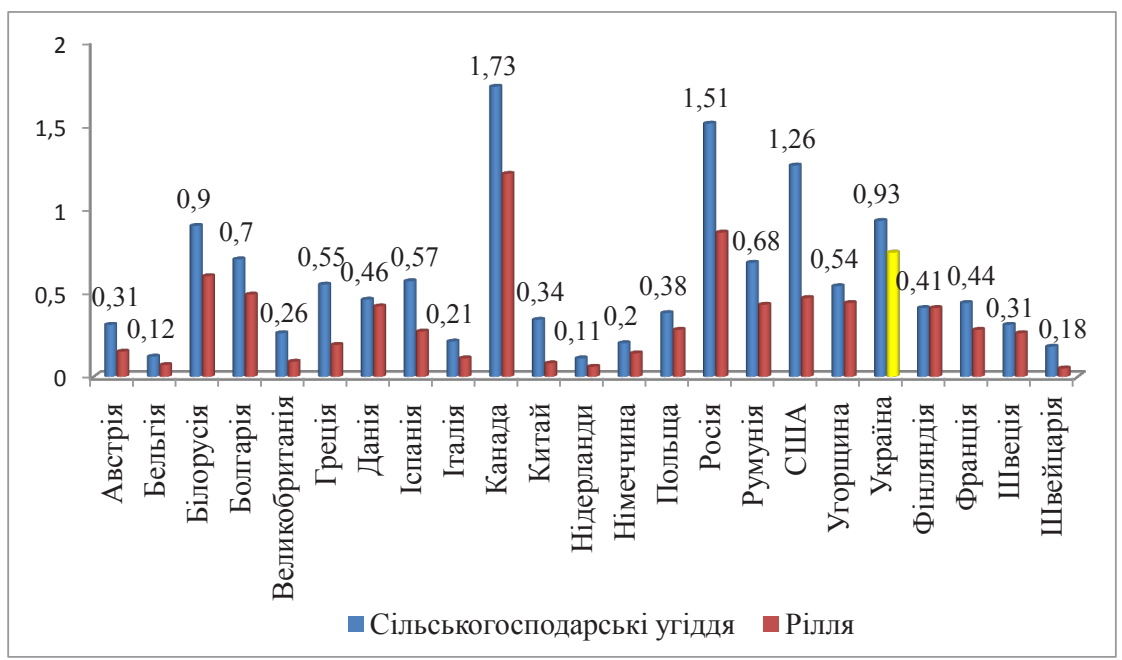

Рис. 1. Площа сільськогосподарських угідь на одного жителя в окремих країнах світу та в Україні, га

Джерело: розраховано, побудовано авторами згідно з даними джерел [9; 10; 12] Зазначимо, що через діючий в Укра-

[8, с. 306]. У структурі площ сільськогосподарських угідь 78,4\% займає рілля, 13,1\% - пасовища, 5,8\% сіножаті (табл. 1).

Як показують дані табл. 1, динаміка земельних ресурсів за 2010-2017 рр., зокрема площа сільськогосподарських угідь, характеризується тенденцією до скорочення на $0,2 \%$, проте для ріллі характерне зростання на $0,2 \%$. Попри зменшення обсягів земельних ресурсів, Україна продовжує займати одну з лідируючих позицій у світі за показником площі сільськогосподарських угідь та ріллі на одного жителя (рис. 1). Так, за площею сільськогосподарських угідь на одного жителя лідером $є$ Канада $з$ показником 1,73 га, другу позицію займає Росія (1,51 га), третю - США (1,26 га). Україна посідає четверте місце у світі за обсягом сільськогосподарських угідь у розрахунку на одного жителя з показником 0,93 га, а за обсягом ріллі на одного жителя - друге місце $(0,74$ га). Зазначимо, що наведенні показники, 3 одного боку, свідчать про забезпеченість великими обсягами землі всіх жителів країни та достатність сільськогосподарських угідь для розвитку сімейного фермерства, а з іншого боку, про відсутність резервів для зростання земельних ресурсів.

В результаті проведення земельної реформи в Україні сформовано основи нових земельних відносин та нового земельного устрою. Останній передбачав поступову передачу державної та колективної власності на землю у приватну власність, що впродовж кількох наступних років привело до суттєвих змін у структурі власності земельного фонду. Земля в Україні може перебувати у приватній, комунальній та державній власності. Іноземні громадяни можуть набувати права власності лише на землі несільськогосподарського призначення. Обіг земель сільськогосподарського призначення в Україні $є$ досить статичним через діючу заборону на відчуження земель сільськогосподарського призначення (мораторій), що була встановлена у 2002 р.

Таблиця 1

Динаміка земельних ресурсів України у 2010-2017 рр., тис. га

\begin{tabular}{|c|c|c|c|c|c|c|c|c|}
\hline \multirow{2}{*}{ Вид земельних угідь } & \multicolumn{7}{|c|}{ Роки } & \multirow{2}{*}{$\begin{array}{l}2017 \text { p. y \% } \\
\text { до } 2010 \text { p. }\end{array}$} \\
\hline & 2010 & 2012 & 2013 & 2014 & 2015 & 2016 & 2017 & \\
\hline $\begin{array}{l}\text { Сільськогосподарські } \\
\text { угіддя, всього: }\end{array}$ & 41576,0 & 41536,3 & 41525,8 & 41511,7 & 41507,9 & 41504,9 & 41489,3 & 99,8 \\
\hline зокрема, рілля & 32476,5 & 32518,4 & 32525,5 & 32531,1 & 32541,3 & 32543,4 & 32544,3 & 100,2 \\
\hline багаторічні насадження & 896,5 & 894,3 & 893,5 & 892,9 & 892,4 & 897,1 & 894,8 & 99,8 \\
\hline перелоги & 310,2 & 253,5 & 251,2 & 239,4 & 233,7 & 230,6 & 229,3 & 73,9 \\
\hline сіножаті & 2410,9 & 2410,5 & 2408,8 & 2407,3 & 2406,4 & 2402,9 & 2399,4 & 99,5 \\
\hline пасовища & 5481,9 & 5459,6 & 5446,8 & 5441,0 & 5434,1 & 5430,9 & 5421,5 & 98,9 \\
\hline
\end{tabular}

Джерело: розраховано, побудовано авторами згідно з даними джерела [8, с. 306] 
їні мораторій заборонено здійснювати продаж, дарування, передачу в заставу або інші способи відчуження 96\% усіх земель сільськогосподарського призначення, що перебувають в усіх формах власності.

У загальній структурі власності на землю на початку 2018 р. у приватній власності перебували 74,9\%, державній - 24,1\%, комунальній - 1,06\%, а лише 0,04\% припадали на колективну власність на землі сільськогосподарського призначення (рис. 2).

Значний вплив на структуру земельного фонду України має динаміка перерозподілу площі сільськогосподарських угідь серед діючих сільськогосподарських підприємств щодо великих інтегрованих компаній, тобто агрохолдингів. Варто зазначити, що за останні дев'ять років кількість підприємств, земельний банк яких становить понад 10000 га, збільшився на 97 одиниць, а їхній земельний банк - на 2622 тис. га, дорівнюючи у 2017 р. 3528 тис. га. Так, якщо у 2007 р. частка земельного банку у структурі загальної площі сільськогосподарських угідь становила 4,4\%, то у 2017 р. вона зросла до 17\% [2].

Сьогодні в Україні нараховується більше 100 великих агрохолдингів, які обробляють більше 6 329,05 тис. га землі. Такі структури активно інвестують фінансові активи в аграрний сектор економіки України (табл. 2).

Проведений аналіз даних табл. 1 показує, що у 2017 р. загальна площа ста агрохолдингів становила 6329,1 тис. га, тобто зменшилась на 52,1 тис. га порівняно з 2012 р.

Агрохолдинги відіграють важливу роль у формуванні сільськогосподарського ринку України. Так, частка холдингів у загальному обсязі експорту $\epsilon$ вищою, ніж інших сільськогосподарських підприємств у загальному виробництві цих культур (за винятком сої). У 2017 р. обсяг валового виробництва сільськогосподарської продукції агрохолдингів дорівнював 55,9 млрд грн., що складає 22\% від загального обсягу виробництва продукції в країні, що на 1\% менше показника 2016 року [2].

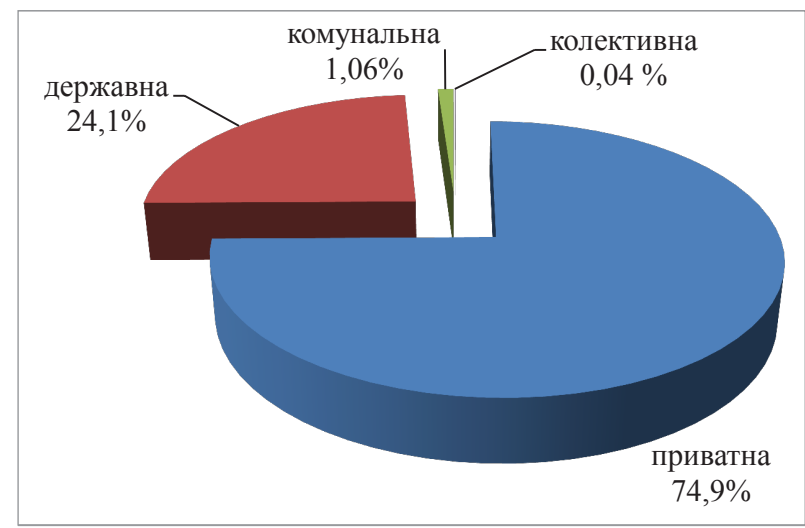

Рис. 2. Структура власності на землі сільськогосподарського призначення (станом на початок 2018 року), \%

Джерело: побудовано авторами на основі джерела [3]

Велике значення в дослідженні ефективності використання земельних ресурсів мають сільськогосподарські підприємства. Аналіз структури сільськогосподарських підприємств України свідчить про те, що їх більшість має невелику площу землекористування (табл. 3).

Так, на 1 листопада 2017 р. в Україні налічувалося 20932 сільськогосподарських підприємства 3 площею сільськогосподарських угідь до 50 га, що складає 45,9\% їх загальної кількості, які використовували 516,3 тис. га сільськогосподарських угідь. Тим часом у 304 сільськогосподарських підприємствах, які складали $0,7 \%$ їх загальній кількості, використовувалося більше 7000 га сільськогосподарських угідь. Відповідно, на такі підприємства припадали 24\% загальної площі сільськогосподарських угідь.

Отже, дослідження параметрів розвитку аграрної структури в Україні дає змогу відзначити ії особливості, які характеризуються переорієнтацією в структурі виробництва продукції сільського господарства на особисті селянські господарства, а також значним подрібненням землекористування сільськогосподарських підприємств.

Таблиця 2

Земельні ресурси 10 найбільших агрохолдингів України за 2012-2017 рр.

\begin{tabular}{|c|c|c|c|c|c|c|}
\hline \multirow{2}{*}{ Назва агрохолдингу } & \multicolumn{6}{|c|}{ Площа земельного банку, тис. га } \\
\hline & 2012 p. & 2013 p. & 2014 p. & 2015 p. & $2016 \mathrm{p}$. & 2017 p. \\
\hline Ukrlandfarming & 532 & 670 & 670 & 654 & 605 & 605 \\
\hline Агропросперіс & 400 & 405 & 405 & 430 & 430 & 602,5 \\
\hline Кернел груп & 369 & 400 & 400 & 390 & 385 & 430 \\
\hline Мрія Агрохолдинг & 295 & 315 & 320 & 360 & 370 & 370 \\
\hline Миронівський хлібопродукт & 280 & 295 & 261 & 261 & 250 & 250 \\
\hline Українські аграрні інвестиції & 260 & 260 & 320 & 245 & 220 & 185 \\
\hline Астарта - Київ & 245 & 245 & 245 & 180 & 185 & 151 \\
\hline HarvEast & 220 & 204 & 197 & 150 & 151 & 137 \\
\hline Агротон & 209 & 160 & 151 & 136,7 & 137 & 127 \\
\hline Sintal Agriculture & 150 & 150 & 150 & 130 & 127 & 122 \\
\hline $\begin{array}{l}\text { Загальна земельна площа } \\
\text { ста найбільших агрохолдингів }\end{array}$ & 6381,2 & 6593,1 & 5956,1 & 6425,2 & 6326,3 & 6329,1 \\
\hline
\end{tabular}

Джерело: сформовано авторами на основі даних джерела [2] 
Структура діючих сільськогосподарських підприємств України за розміром сільськогосподарських угідь на 1 листопада 2017 р.

\begin{tabular}{|l|c|c|c|c|}
\hline $\begin{array}{c}\text { Розміри } \\
\text { сільськогосподарських } \\
\text { підприсмств }\end{array}$ & $\begin{array}{c}\text { Кількість } \\
\text { підприсмств }\end{array}$ & $\begin{array}{c}\text { Відсоток } \\
\text { до загальної } \\
\text { кількості }\end{array}$ & $\begin{array}{c}\text { Пллоща } \\
\text { сільськогосподарських } \\
\text { угідь, тис. га }\end{array}$ & $\begin{array}{c}\text { Відсоток } \\
\text { сільськальної площі } \\
\text { угідьь }\end{array}$ \\
\hline $\begin{array}{l}\text { Підприємства, що мали } \\
\text { сільськогосподарські угіддя }\end{array}$ & 40735 & 89,4 & 19960,2 & 100,0 \\
\hline зокрема, площею (га) до 5,0 & 3138 & 6,9 & 10,1 & 0,1 \\
\hline $5,1-10,0$ & 2594 & 5,7 & 20,3 & 0,1 \\
\hline $10,1-20,0$ & 3937 & 8,6 & 61,0 & 2,1 \\
\hline $20,1-50,0$ & 11263 & 24,7 & 424,9 & 1,8 \\
\hline $50,1-100,0$ & 4903 & 10,8 & 354,3 & 9,0 \\
\hline $100,1-500,0$ & 7372 & 16,2 & 1797,1 & 9,5 \\
\hline $500,1-1000,0$ & 2651 & 5,8 & 1891,4 & 17,8 \\
\hline $1000,1-2000,0$ & 2481 & 5,4 & 3570,9 & 8,3 \\
\hline $2000,1-3000,0$ & 1084 & 2,4 & 2649,2 & 6,2 \\
\hline $3000,1-4000,0$ & 471 & 1,0 & 1635,4 & 7,2 \\
\hline $4000,1-5000,0$ & 276 & 0,6 & 1236,1 & 5,7 \\
\hline $5000,1-7000,0$ & 261 & 0,6 & 1526,3 & 18,3 \\
\hline $7000,1-10000,0$ & 138 & 0,3 & 1140,1 & - \\
\hline більше 10 000,0 & 166 & 0,4 & 3643,1 & \\
\hline $\begin{array}{l}\text { Підприємства, що не мали } \\
\text { сільськогосподарських угідь }\end{array}$ & 4823 & 10,6 & & \\
\hline
\end{tabular}

Джерело: розраховано авторами на основі джерела [7, с. 173]

Зазначимо, що за останні 5 років у сільськогосподарських підприємствах середньорічне скорочення сільськогосподарських угідь складало 23,5 тис. га, у господарствах населення спостерігався середньорічний приріст, який складав 3,2 тис. га. У 2017 р. площа сільськогосподарських угідь сільськогосподарських підприємств становила 20759,1 тис. га, що на 12,1 тис. га, тобто на 1,7\%, більше, ніж у попередньому році. 3 цієї площі 20 012,1 тис. га ріллі, тобто ії частка в площі сільськогосподарських угідь склала 96,4\% [6].

Україна має надзвичайно високий рівень освоєння земельного фонду та розораності сільськогосподарських угідь. За розораністю вона посідає перше місце у світі, що в середньому становить 78,2\%. Надмірна розораність приводить до збільшення площі еродованих сільськогосподарських угідь, яких у нашій державі вже близько 15 млн. га. Саме тому за нераціонального використання орних земель поширюються процеси деградації грунтів, поверхня яких піддається ерозії, перезволоженню, підвищується кислотність тощо. Сформовані негативні тенденції потребують оптимізації земельного фонду України, зокрема вжиття заходів щодо вилучення з інтенсивного обробітку деградованих та малопродуктивних земель, до яких належать сільськогосподарські угіддя, які мають низьку родючістю, господарське використання яких за призначенням стало економічно неефективним [1].

Рівень ефективності використання сільськогосподарських угідь характеризує коефіцієнт розораності, який визначається відношенням площі ріллі до площ сільськогосподарських угідь.
Проведений аналіз регіонів за площею сільськогосподарських угідь та рівнем розораності показує, що найбільші площі сільськогосподарських угідь мають Одеська (6,1\% загальної площі сільськогосподарських угідь України), Дніпропетровська $(6,0 \%)$, Харківська $(6,0 \%)$, Запорізька $(5,8 \%)$, Вінницька $(5,0 \%)$ та Полтавська (5,0\%) області. Рівень розораності для цих регіонів не є найвищим (рис. 3).

Для зручності проведення аналізу доцільно здійснити групування регіонів України за показниками площ сільськогосподарських угідь та рівнем розораності. Як групувальна ознака вибрана площа сільськогосподарських угідь.

Задля визначення необхідної кількості груп використано формулу Стерджесса:

$$
n=1+13.322 \ln N=1+13.322 \ln 24=5.4 .
$$

Отже, приймаємо, що $n=5$.

Результати проведених розрахунків показують, що необхідно формувати п'ять груп з рівними інтервалами. Додатковим показником для проведення аналізу $\epsilon$ коефіцієнт розораності, який визначено для кожної групи за формулою середньої арифметичної зваженої.

Отже, за результатами обчислень здійснено групування регіонів України, які представлено в табл. 4.

Як показують дані табл. 4, зі збільшенням площ сільськогосподарських угідь по регіонах також зростає ефективність їхнього використання. Оцінюючи розподіл щодо географічного розташування регіонів, зазначаємо, що південні та південно-східні регіони спеціалізуються на вирощуванні зернових культур. Західні та центральні області володіють значним земельним 


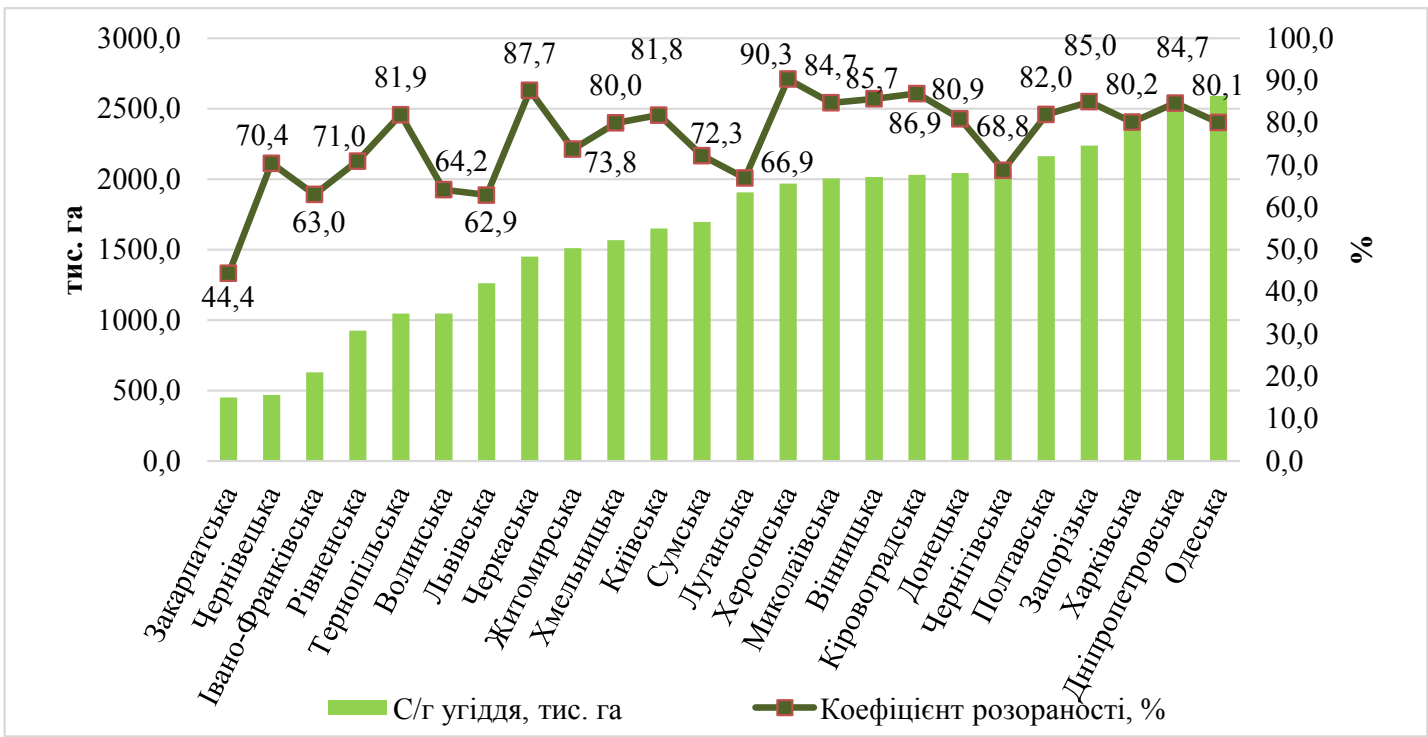

Рис. 3. Площа сільськогосподарських угідь та рівень розораності в регіонах України (станом на 1 січня 2018 р.)

Джерело: розраховано, побудовано авторами за даними джерел [7; 8]

потенціалом, який дасть змогу зі збільшенням площ під сівбу сільськогосподарських культур наростити обсяги валової продукції сільського господарства.

У 2017 р. посівні площі сільськогосподарських культур в Україні зросли на 1,5\% порівняно з 2016 р. У регіональному розрізі позитивний приріст спостерігався в усіх областях України (в межах від $0,1 \%$ до 5,9\%), окрім Вінницької, Закарпатської та Черкаської областей. Найбільший приріст був характерний для посівів технічних культур, зокрема ріпаку (на 79,2\%), сої (на 8,6\%), а також таких зернових, як горох (на 71,4\%), гречка (на 18,9\%), жито (на 17,5\%) [8].

Збільшення площ посівів в Україні у 2017 р. привело до отримання більшого врожаю. Проте варто відзначити, що збільшення валових зборів відбулось переважно за рахунок екстенсивного чинника, а саме зростання площ, і лише для окремих культур за рахунок зростання урожайності. Дані про збирання врожаю за окремими видами сільськогосподарських культур у господарствах усіх категорій представлено в табл. 5 .

Задля проведення більш грунтовного дослідження результатів здійснено міжнародні порівняння урожайності основних сільськогосподарських культур. Це дало змогу відзначити, що Україна недостатньо ефективно вживає агротехнічних заходів, які мають бути спрямовані на підвищення врожайності та отримання урожаю. Показники врожайності пшениці, соняшника, цукрового буряка та картоплі в окремих країнах світу у 2017 р. показують, що в Україні рівень урожайності $\epsilon$ одним 3 найнижчих (рис. 4).

Аналіз урожайності основних сільськогосподарських культур в Україні за категоріями виробників показав, що найменш ефективно використовується земля господарствами населення. Так, у 2017 р. рівень урожайності зернових та зернобобових культур у господарствах населення був на 24\% нижчим, ніж у сіль-

Таблиця 4

Групування регіонів України за площею сільськогосподарських угідь та рівнем розораності (станом на 1 січня 2018 р.)

\begin{tabular}{|c|l|c|c|}
\hline $\begin{array}{c}\text { Розмір } \\
\text { сільськогосподарських } \\
\text { угідь, тис. га }\end{array}$ & \multicolumn{1}{|c|}{ Області } & $\begin{array}{c}\text { Середня площа } \\
\text { сільськогосподарських } \\
\text { угідь, га }\end{array}$ & $\begin{array}{c}\text { Коефіціснт розораності, } \\
\text { \% }\end{array}$ \\
\hline $451,3-879,4$ & $\begin{array}{l}\text { Закарпатська, Чернівецька, } \\
\text { Івано-Франківська. }\end{array}$ & 517,0 & 59,9 \\
\hline $879,4-1307,4$ & $\begin{array}{l}\text { Рівненська, Волинська, Тернопільська, } \\
\text { Львівська. }\end{array}$ & 1069,7 & 78,9 \\
\hline $1307,4-1735,5$ & $\begin{array}{l}\text { Черкаська, Житомирська, Хмельницька, } \\
\text { Київська, Сумська. }\end{array}$ & 2575,6 & 80,6 \\
\hline $1735,5-2163,5$ & $\begin{array}{l}\text { Луганська, Херсонська, Миколаївська, } \\
\text { Вінницька, Кіровоградська, Донецька, } \\
\text { Чернігівська. }\end{array}$ & 2005,7 & 82,3 \\
\hline $2163,5-2 ~ 591,6$ & $\begin{array}{l}\text { Полтавська, Запорізька, Харківська, } \\
\text { Дніпропетровська, Одеська. }\end{array}$ \\
\hline
\end{tabular}

Джерело: розраховано авторами на основі даних джерела [7] 
Збирання врожаю за окремими видами сільськогосподарських культур в Україні в усіх категоріях господарств

\begin{tabular}{|c|c|c|c|c|c|c|}
\hline \multirow[b]{2}{*}{$\begin{array}{c}\text { Сільськогосподарські } \\
\text { культури }\end{array}$} & \multicolumn{2}{|c|}{ Зібрана площа, тис. га } & \multicolumn{2}{|c|}{ Обсяг виробництва, тис. ц } & \multicolumn{2}{|c|}{ Урожайність, ц 31 га } \\
\hline & 2017 p. & $\begin{array}{c}2017 \text { p. y \% } \\
\text { до } 2016 \text { p. }\end{array}$ & 2017 p. & $\begin{array}{c}2017 \text { у \% } \\
\text { до } 2016 \text { p. }\end{array}$ & 2017 p. & $\begin{array}{l}2017 \text { y \% } \\
\text { до } 2016 \text { p. }\end{array}$ \\
\hline Пшениця яра & 199,4 & 106,5 & 7774,4 & 104,0 & 39,0 & 97,5 \\
\hline Жито озиме & 169,5 & 119,4 & 5191,0 & 128,2 & 30,6 & 107,4 \\
\hline Гречка & 173,8 & 117,9 & 1928,7 & 101,0 & 11,1 & 85,4 \\
\hline Горох & 411,9 & 173,0 & 11387,1 & 147,1 & 27,6 & 84,9 \\
\hline Кукурудза на зерно & 2975,5 & 106,5 & 147043,7 & 85,3 & 49,4 & 80,1 \\
\hline Соя & 1691,9 & 101,6 & 33447,5 & 85,3 & 19,8 & 83,9 \\
\hline Ріпак озимий та ярий & 780,5 & 173,1 & 22233,5 & 188,1 & 28,5 & 108,8 \\
\hline
\end{tabular}

Джерело: розраховано авторами на основі даних джерела [7]

ськогосподарських підприємств, цукрового буряка та картоплі - на 30\%, овочевих культур - на 58\% (рис. 5).

Проблемою для України залишається нераціональне та виснажливе використання сільськогосподарських земель. Для подолання неефективного використання сільськогосподарських земель в Україні ще у 2003 р. затверджено Концепцію збалансованого розвитку агроекосистем в Україні на період до 2025 р. У Концепції представлено заходи, вжиття яких сприятиме формуванню збалансованої (сталої) системи природокористування в сільському господарстві та забезпеченню розбудови екомережі [5].
Сьогодні загострює проблему становлення засад раціонального використання сільськогосподарських угідь посилення екологічних дисбалансів, що зумовлене порушенням науково обгрунтованих положень господарювання та виробництва сільськогосподарської продукції (агротехнічні вимоги вирощування сільськогосподарських культур, система сівозмін, інноваційні технології обробітку грунту та догляду за посівами), дисбалансами розвитку рослинницької та тваринницької галузей, що обмежує параметри внесення органічних добрив у грунт і стримує відтворення природної родючості останнього,

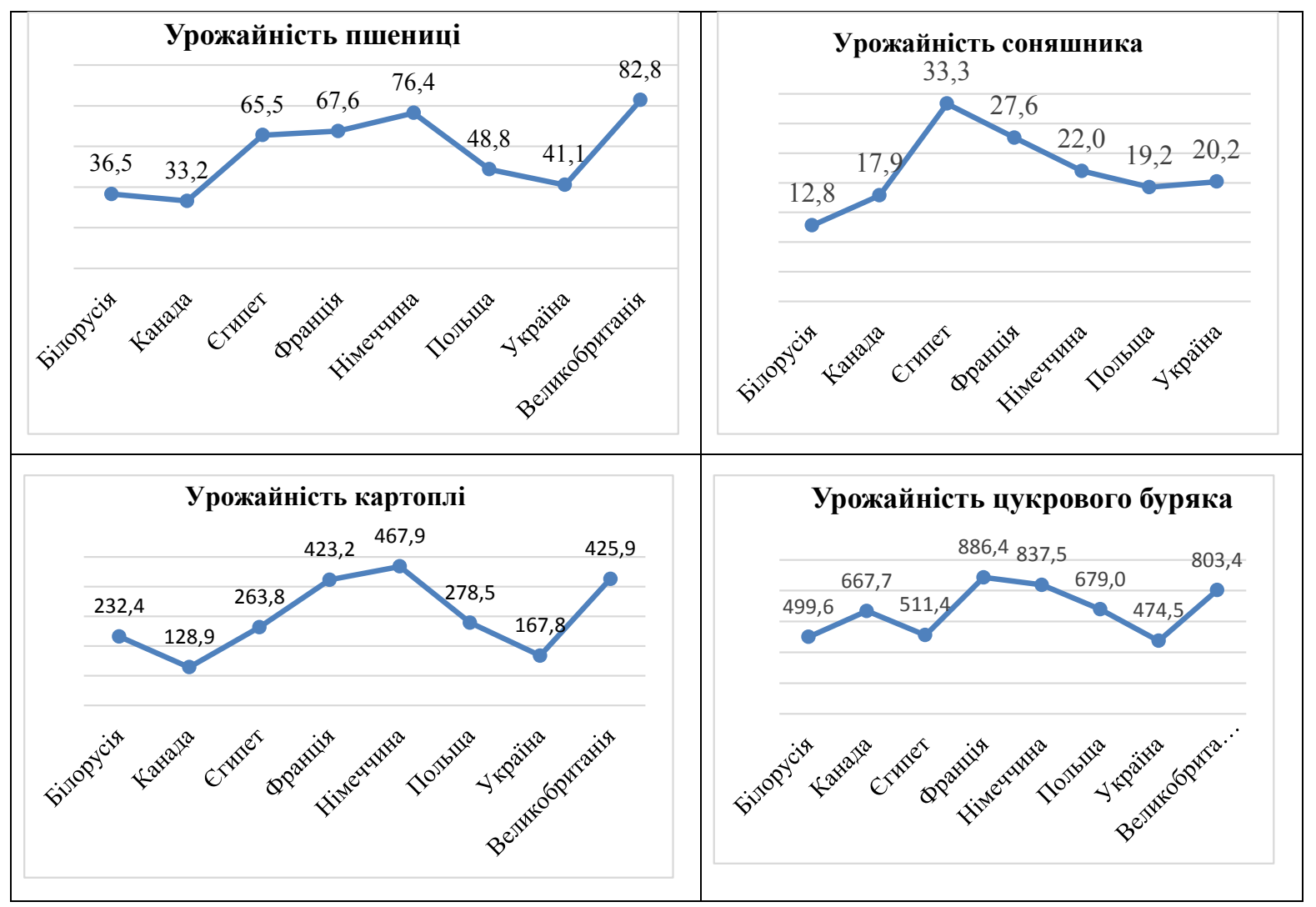

Рис. 4. Урожайність пшениці, соняшника, цукрового буряка та картоплі в Україні та окремих країнах світу, ц/га

Джерело: побудовано авторами за даними джерела [11] 
Культури плодові та ягідні

Культури овочеві

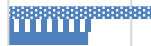

Картопля

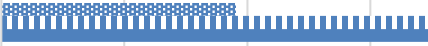

Соняшник

Буряк цукровий фабричний

Культури зернові та зернобобові

\section{in}

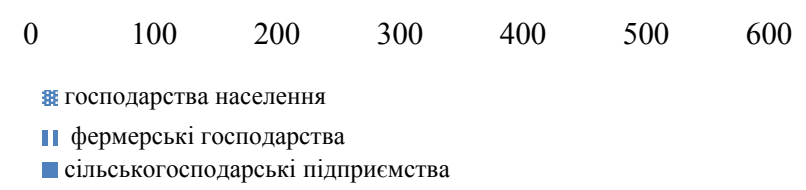

Рис. 5. Урожайність основних сільськогосподарських культур та їх груп в Україні у 2017 p. за категоріями виробників, ц/га

Джерело: побудовано авторами за даними джерела [7]

тотальною інтенсифікацією виробничо-господарської діяльності в аграрному секторі, посиленням антропогенного навантаження на екосистеми сільських територій, недостатнім рівнем відповідальності власників суб'єктів господарювання в аграрному секторі за можливі наслідки поглиблення економічних дисбалансів, мізерними розмірами штрафів та санкцій за порушення норм екологічного законодавства.

На наш погляд, підвищення ефективності використання земельних ресурсів передбачає доцільність дотримання стратегічної орієнтації на досягнення таких пріоритетів, як формування інституційного базису для поетапного впровадження ринку земель сільськогосподарського призначення, подолання проявів практики тіньового обігу сільськогосподарських угідь, мінімізація ризиків надмірної концентрації землі у користуванні одного власника, усунення екологічних дисбалансів розвитку аграрного сектору України, узгодження ресурсних потужностей з екологічними ризиками функціонування, організація засад раціонального природокористування в сільському господарстві, посилення охорони земель сільськогосподарського призначення, запобігання процесам деградації грунтового покриву, забезпечення відтворення та збереження родючості сільськогосподарських угідь.

Досягнення визначених стратегічних пріоритетів передбачає доцільність комплексного вжиття таких заходів:

- системне подолання інституційних бар'єрів та інституційних пасток на шляху впровадження ринку обігу земель сільськогосподарського призначення шляхом завершення процесу інвентаризації та кадастрового оцінювання сільськогосподарських угідь, формування комплексного інституційного базису регулювання земельних відносин в аграрному секторі економіки, проведення інформаційної кампанії серед населення щодо наявності дестабілізуючого впливу ризиків та загроз відсутності сформованості ринку земель сільськогосподарського призначення, усунення інституційних прогалин щодо врегулювання земельних спорів між суб'єктами аграрних відносин, подолання наявного лобі в органах державної влади щодо блокування поетапного впровадження ринку землі сільськогосподарського призначення;

- проектування та розроблення пріоритетної компромісної моделі функціонування ринку земель сільськогосподарського призначення, яка б максимально задовольняла інтереси всіх суб' єктів аграрного сектору економіки, гарантувала формування базисних передумов для нівелювання загроз національній безпеці на засадах врахування таких структурних аспектів, як унеможливлення купівлі сільськогосподарської землі іноземцями, обов'язкове встановлення максимального обсягу володіння земельним банком, реалізація механізмів моніторингу й контролю використання сільськогосподарських угідь на умовах дотримання вимог раціонального природокористування;

- протидія системним проявам функціонування незаконного тіньового ринку обігу сільськогосподарських угідь шляхом унеможливлення зміни цільового призначення останніх, боротьби з практикою фактичної прихованої купівлі-продажу земельних ділянок на засадах використання інструментів емфітевзису та довгострокових договорів оренди, вжиття правоохоронних заходів та впровадження практики доведення до судових рішень справ, пов'язаних із незаконних захопленням землі сільськогосподарського призначення, впровадження практики обов'язкового нотаріального оформлення договорів оренди сільськогосподарських угідь у населення, протидії поширенню усталеної практики натуральної форми розрахунків за користування сільськогосподарськими паями, вилучення в судовому порядку земельних ділянок, що були передані у власність шляхом порушення норм чинного законодавства;

- у сфері землекористування сільськогосподарських угідь на засадах оптимізації структури посівних площ 
відповідно до вимог і специфіки розташування виробничо-господарських потужностей в конкретній природно-кліматичній зоні вжиття зрошувальних, осушувальних та меліоративних заходів, оптимізація рівня розораності сільськогосподарських угідь, посилення моніторингу за використанням у процесі господарської діяльності отрутохімікатів, забезпечення балансу під час внесення мінеральних та органічних добрив, організації системного агрохімічного обстеження грунтів, що розташовані в потенційних зонах ризику, використання інструментів консервації сільськогосподарських угідь, здійснення агрохімічної паспортизації земель сільсько- господарського призначення, впровадження дієвих механізмів громадського контролю за дотримання законодавства у сфері охорони земельних ресурсів.

Висновки. Таким чином, забезпечення орієнтації на досягнення визначених стратегічних пріоритетів підвищення ефективності використання земельних ресурсів України сформує передумови зростання параметрів ефективності реалізації природно-ресурсного потенціалу аграрного сектору, підвищення конкурентних позицій як на внутрішньому, так і зовнішньому ринках, активізації темпів розширеного відтворення сільського господарства.

\section{Список літератури:}

1. Бабміндра Д.І. Класифікація грунтів України як наукова передумова екологобезпечного землекористування для покращення міжнародної інвестиційної діяльності : монографія. Київ, 2010. 780 с.

2. Бондарь К.М. ТОП-100 латифундистов Украины. 2017. Національний агропортал "Latifundist". URL: http://latifundist.com/rating/top100latifundistov-ukrainy (дата звернення: 30.07.2019).

3. Державна служба України з питань геодезії, картографії та кадастру. URL: https://land.gov.ua (дата звернення: 06.08.2019).

4. Земельний кодекс України від 25 жовтня 2001 р. № 2768-III. URL: http://search.ligazakon.ua/1_doc2.nsf/link1/ T012768.html (дата звернення: 30.07.2019).

5. Концепція збалансованого розвитку агроекосистем в Україні на період до 2025 р. : Наказ Міністерства аграрної політики України від 20 серпня 2003 р. № 280. URL: https://zakon.rada.gov.ua/rada/show/v0280555-03 (дата звернення: 06.08.2019).

6. Посівні площі сільськогосподарських культур під урожай 2017 р. : статистичний бюлетень / Державна служба статистики України. Київ, 2017. 49 с.

7. Сільське господарство України за 2017 р. : статистичний збірник / Державна служба статистики України. Київ, 2018. 245 с.

8. Статистичний щорічник України за 2017 р. : статистичний збірник / Державна служба статистики України. Київ, 2018. 541 с.

9. Agricultural area. URL: http://www.fao.org/faostat/en/\#data/RL (дата звернення: 05.08.2019).

10. Arable land. URL: http://www.fao.org/faostat/en/\#data/RL (дата звернення: 05.08.2019).

11. Food and Agriculture Organization of the United Nations. URL: http://www.fao.org/faostat (дата звернення: 05.08.2019).

12. Population. URL: http://www.fao.org/faostat/en/\#data/OA (дата звернення: 05.08.2019).

\section{References:}

1. Babmindra D.I. (2010). Klasyfikatsiya gruntiv Ukrayiny, yak naukova peredumova ekolohobezpechnoho zemlekorystuvannya dlya pokrashchennya mizhnarodnoyi investytsiynoyi diyalnosti [Classification of soils of Ukraine as a scientific prerequisite for green using land for Improving international investment activity]. Kyiv.

2. Bondar K.M. TOP-100 latyfundystov Ukrayny 2017 [TOP-100 latifundists of Ukraine 2017]. Natsionalnyy ahroportal "Latifundist". Retrieved from: http://latifundist.com/rating/top100latifundistov-ukrainy (accessed: 30.07.2019).

3. Derzhavna sluzhba Ukrayiny z pytan heodeziyi, kartohrafiyi ta kadastru [State Service of Ukraine for Geodesy, Cartography and Cadastre]. Retrieved from: https://land.gov.ua (accessed: 06.08.2019).

4. Zemelnyi Kodeks Ukrayiny [Land Code of Ukraine] (2001, October 25). Retrieved from: http://search.ligazakon.ua/1 doc2.nsf/link1/T012768.html (accessed: 30.07.2019).

5. Nakaz Ministerstva ahrarnoyi polityky Ukrayiny "Kontseptsiya zbalansovanoho rozvytku ahroekosystem v Ukrayini na period do 2025 r.” vid 20 serp. 2003 r. № 280 [Order of the Ministry of Agrarian Policy of Ukraine Concept of balanced development of agroecosystems in Ukraine for the period up to 2025 activity from August 20 2003, № 280]. Retrieved from: https://zakon.rada.gov.ua/rada/show/v0280555-03 (accessed: 06.08.2019).

6. Posivni ploshchi silskohospodarskykh kultur pid urozhay 2017 r. : statystychnyi biuleten [The acreage crops under the crop in 2017 : Statistical Yearbook]. (2017). Kyiv : Derzhavna sluzba statystyky Ukrainy.

7. Silske hospodarstvo Ukrainy za 2017 r. : statystychnyi zbirnyk [Agriculture of Ukraine over 2017 : Statistical Yearbook] (2018). Kyiv : Derzhavna sluzba statystyky Ukrainy.

8. Statystychnyy shchorichnyk Ukrayiny za 2017 r. : statystychnyi zbirnyk [Statistical Yearbook of Ukraine for 2017 : Statistical Yearbook] (2018). Kyiv : Derzhavna sluzba statystyky Ukrainy.

9. Agricultural area. Retrieved from http://www.fao.org/faostat/en/\#data/RL (accessed: 05.08.2019). (in Ukrainian)

10. Arable land. Retrieved from: http://www.fao.org/faostat/en/\#data/RL (accessed: 05.08.2019).

11. Food and Agriculture Organization of the United Nations. Retrieved from: http://www.fao.org/faostat (accessed: 05.08.2019).

12. Population. Retrieved from: http://www.fao.org/faostat/en/\#data/OA (accessed: 05.08.2019). 


\section{АНАЛИЗ СОСТОЯНИЯ И ЭФФЕКТИВНОСТИ ИСПОЛЬЗОВАНИЯ ЗЕМЕЛЬНЫХ РЕСУРСОВ В УКРАИНЕ}

В статье исследованы состояние и эффективность использования земельных ресурсов государства. Проанализирована структура земельных ресурсов в Украине и в отдельных странах мира. Определено, что наибольшую площзадь в структуре земельного фонда составляют сельскохозяйственные угодья, подтвержден значительныий уровень распаханности этой территории. Охарактеризованы земельные ресурсы крупнейших аграрных холдингов Украины, а также определена структура действующих сельскохозяйственньх предприятий по размеру угодий. Исследован уровень эффективности использования сельскохозяйственных угодий в регионах Украины на основе анализа их площтадей и уровня распаханности, что позволило провести их группировки. Предложены стратегические приоритеты, приведен комплекс мер по повышению эффективности использования земельных ресурсов государства.

Ключевые слова: земельные ресурсы, земли сельскохозяйственного назначения, сельскохозяйственные угодья, уровень распаханности, рынок, сельское хозяйство.

\section{ANALYSIS AND EFFICIENCY OF USING LAND RESOURCES IN UKRAINE}

The state and efficiency of using land resources of the state are researched in the article. It is noted that the largest area in the structure of the land fund of Ukraine is occupied by agricultural lands, the level of plowing of which the state occupies the first place in the world. The structures of land resources in Ukraine and in some countries of the world are analyzed. It has been determined that Canada, Russia and the USA are the leaders in the area of agricultural land and arable land per capita. In the overall rating, Ukraine ranks 4th with $0.93 \mathrm{ha}$, this confirms the high level of availability of land resources. It is proved that the dynamics of the redistribution of agricultural land area among the existing agricultural enterprises in the direction of agrarian holdings, whose land bank is more than 10 thousand ha, has a significant impact on the structure of the farmland of Ukraine. The land resources are characterized and the structure of operating agricultural enterprises by size of lands is defined. The level of utilization of agricultural land in the regions of Ukraine on the basis of their area and the level of plowing, which made it possible to group them are investigated. The gross collection of certain types of crops in Ukraine in all categories of farms, which is characterized by a tendency for growth are analyzed. For the purpose of a thorough study, the yield comparisons of major crops of some countries of the world were compared, the results of which confirm that in Ukraine the yield of such basic crops as wheat, sunflower, sugar beet and potatoes is one of the lowest. In addition, the productivity of basic agricultural crops by category of producers has been investigated, the indicators of which confirm the inefficient use of agricultural land by households with lower yields than agricultural enterprises. In order to balance the existing disparities of using agricultural land, strategic priorities have been proposed and a set of measures to increase the efficiency of utilization of the state's land resources potential has been outlined.

Key words: land resources, agricultural land, farmland, level of plowing, market, agriculture. 